\title{
Aelia Laelia: alegoria e sonhos coletivos na formação negativa da dramaturgia brasileira
}

\author{
Aelia Laelia: allegory and collective dreams \\ in the negative formation of Brazilian dramaturgy
}

\author{
Ivan Delmanto \\ Universidade de São Paulo (USP), São Paulo, São Paulo / Brasil \\ ivandelmanto@yahoo.com.br
}

Resumo: A partir dos conceitos de alegoria, messianismo e de imagem onírica, retirados da obra de Walter Benjamin, o artigo apresenta, de forma inacabada e incompleta, aspectos do processo histórico de formação da dramaturgia brasileira. Procura-se traçar o percurso de formação de uma dramaturgia nacional identificando os limites e avanços do processo de aclimatação das formas e gêneros de origem europeia, escolhendo como objetos algumas obras e autores em que se pode observar a presença de uma dialética entre negatividade e utopia que, não obstante sua diversidade, poderia caracterizar esse trajeto de formação como capaz de gerar obras tão dilaceradas quanto o tecido social que lhes corresponde.

Palavras-chave: teatro; dramaturgia brasileira; alegoria, imagem onírica.

Abstract: From the concepts of allegory, messianism and dream picture, taken from the work of Walter Benjamin, the article presents, in an incomplete and incomplete way, aspects of the historical process of Brazilian dramaturgy. It is sought to trace the course of formation of a national dramaturgy by identifying the limits and advances of the process of acclimatization of forms and genres of European origin, choosing as objects some works and authors in which one can observe the presence of a dialectic between negativity and utopia and how it, not withstanding its own diversity, could characterize this formation course capable of generating new works as lacerated as the social fabric to which they correspond.

Keywords: theater; Brazilian dramaturgy; allegory; dream image 


\section{Fragmento 1 - Origem do que virá}

Nos coros iniciais das tragédias gregas, é muito comum encontrarmos, por meio da rememoração dos mitos que baseiam cada peça teatral, a exposição de toda a narrativa e sequência de ações que será encenada no momento seguinte. Neste primeiro fragmento do artigo, à maneira de um prólogo trágico, apresentaremos uma breve rememoração da pesquisa sobre a história da dramaturgia brasileira, que realizamos nos últimos anos, bem como anteciparemos o enredo que o leitor encontrará em todo o texto, com seus conflitos, instabilidades e percalços. Como diria Walter Benjamin (2013, p. 32), promover a narrativa da origem (Ursprung) deste artigo, é totalmente diferente de escrever uma introdução: "O que é próprio da origem nunca se dá a ver no plano do factual, cru e manifesto. O seu ritmo só se revela a um ponto de vista duplo, que o reconhece, por um lado como restauração e reconstituição, e por outro como algo de incompleto e inacabado". Caminhemos, então, rumo a pré e pós-história de nosso próprio artigo.

Conforme Antonio Candido recorda no "Prefácio" da primeira edição da sua Formação da Literatura Brasileira (1975), o livreiro e editor José de Barros Martins lhe encomendara uma "história da literatura brasileira, das origens aos nossos dias, em dois volumes breves, entre a divulgação séria e o compêndio", mas acabou recebendo, com dez anos de atraso, "apenas" o estudo de dois períodos, verdade que decisivos, a Arcádia e o Romantismo. Decidida a virada do livro - que não seria mais uma história da literatura brasileira - Antonio Candido chegou à conclusão de que um critério interessante seria a articulação das obras e dos escritores, um campo histórico de influências artísticas cruzadas, ao longo do qual se poderia discernir a continuidade de uma tradição. Ao distinguir entre manifestações literárias avulsas e literatura propriamente dita, encarada no livro como um sistema de obras ligadas por denominadores comuns, como um fato de cultura que não surge pronto e acabado, reapontando assim a formação de uma continuidade literária no Brasil, Candido definia a ideia teórica fundamental do livro, a de Sistema Literário.

Procuraremos formular, neste artigo, apontamentos para o panorama de uma espécie de sistema teatral que, diferentemente do sistema literário traçado por Candido, não foi plenamente formado no Brasil. Assim, seria possível dizer, parafraseando nosso crítico literário, que nenhum dos dramaturgos brasileiros que serão mencionados aqui 
"pressupôs a existência de seus antecessores" em um teatro que pudesse "a cada geração aprofundar, fecundar o que havia de certo nas experiências anteriores", por isso a ausência de uma "independência em relação aos contemporâneos europeus, do alheamento às modas" dos países centrais. Para o percurso de nossa dramaturgia, falar em interrupção constante não se trata de pensar "na continuidade pela continuidade", mas do fracasso, em nossa história teatral, na constituição de um campo de problemas reais, particulares, com inserção e duração histórica próprias, que recolha as forças da tradição local e solicite o passo adiante. Não conseguimos, no teatro brasileiro, chegar àquele estágio da formação preconizado por Antonio Candido: "Um estágio fundamental na superação da dependência é a capacidade de produzir obras de primeira ordem, influenciadas não por modelos estrangeiros imediatos, mas por exemplos nacionais anteriores"(CANDIDO, 1989, p.153).

Formação da literatura brasileira funciona como marco tanto para as expectativas dos pensadores do Brasil imediatamente precedentes ou contemporâneos ao livro quanto para o presente: "É como se nos dissesse que, de fato, ocorreu um processo formativo no Brasil e que houve esferas - no caso, a literária - que se completaram de modo muitas vezes até admiráveis, sem que por isso o conjunto esteja em vias de se integrar" (SCHWARZ, 1999, p.58). No caso da dramaturgia brasileira, escrita para ser encenada, o horizonte incompleto do texto teatral, que exige a materialização do espetáculo, permaneceu como parte daquele conjunto social desintegrado: ao contrário da literatura, formada graças a um grau considerável de organização mental das elites locais, a história teatral - dependente da concretude da mão-de-obra qualificada de técnicos, diretores e atores; de modos de produção artística variados (cenografia, música, figurino, texto, cena), integrados à circulação permanente de um mercado consumidor consolidado; da existência e da estrutura dos edifícios teatrais; e da formação de um público vasto, capaz de ser ver representado nas obras apresentadas -, constituiu-se a partir de processos cultural e econômico particulares. $\mathrm{Na}$ verdade - e a pesquisa realizada nos apontou isso até agora -, esse processo de formação peculiar, por ser material e intelectual ao mesmo tempo, reflete os impasses da formação negativa da própria nação.

Diante de um quadro atual no qual tudo indicaria ser impossível que "nossa sociedade venha a se reproduzir de maneira consistente", Roberto Schwarz (1999, p.58), refletindo sobre o clássico livro de 
Antonio Candido, pergunta-se: "como fica a própria ideia de formação?". $\mathrm{Na}$ conclusão do texto, o ensaísta sumariza perspectivas possíveis para o encaminhamento desse debate. A hipótese que nos interessa é especialmente sugestiva para a revisão dos juízos a respeito da formação do teatro brasileiro: diz respeito a que essa ideia/ideal estaria reduzida à miragem, à aspiração sem respaldo no atual concerto global. O andamento da história teria inviabilizado o projeto passado; visto hoje, o contraste entre anseios e resultados atestaria a ilusão da ambição formadora: "A nação não vai se formar, as suas partes vão se desligar umas das outras, o setor "avançado" da sociedade brasileira já se integrou à dinâmica mais moderna da ordem internacional e deixará cair o resto"(Idem, ibidem). Essa possibilidade para o rumo das coisas, no extremo, conduziria ao abandono de qualquer empenho formativo tradicional.

Assim, seria possível identificar, no plano da história da dramaturgia brasileira, uma gradativa constituição de uma configuração nacional com feição e dinamismo próprios. Traçar um trajeto para essa formação teatral significa apresentar a crônica de uma deformação ou, mais precisamente, de uma formação negativa. Para José Antonio Pasta Junior (2010, p. 11), é possível dizer sobre o romance brasileiro: "Há bastante tempo [...] dei-me conta de que era necessário opor à "formação", tradicionalmente compreendida, a noção de uma não-formação radical, vigente ao mesmo tempo no plano do sujeito, das obras e da sociedade/história". Nesse sentido, o que aparentava ser extemporâneo - a forma em ruína e o desconexo - que absorveram nossa atenção, partindo de obras teatrais decisivas, mas que, talvez por isso mesmo, não apresentam proporção e sincronia das partes em um todo harmonioso, como preconizavam seus modelos europeus, mas "curva deceptiva e terminal" (Idem, ibd.), em aparente nulidade e fracasso. É possível, ao partir dessa mirada sobre a formação, que aproxima a ideia de negação à de aniquilamento, identificar uma espécie de processo de constituição negativa do teatro no Brasil, representado por autores e obras que dissolveram os modelos originais europeus em tecidos textuais dilacerados por contradições múltiplas e aparentemente insuperáveis. Pude constatar, na análise de uma infinidade de textos teatrais, que o jogo das oposições impõe à cada forma dramatúrgica um incessante movimento pendular entre extremos que nunca encontram um momento de síntese. Os conflitos surgem assim registrados em movimento cíclico permanente, em um "eterno" retorno do negativo, em que a aparência e a essência, o drama e o épico, o interior e o exterior se confundem de maneira quase indissolúvel. 
Sob aparente regime de mera importação, na verdade esses textos dramatúrgicos nacionais escapam da identificação com as formas hegemônicas dos modelos europeus, mas essa diferenciação se dá apenas em parte, por meio do deslocamento, da ruína, da negação e da corrosão que, se não podem inaugurar uma nova forma - daí a melancolia presente no tecido das obras, marcado por alegorias, por traumas e pelo fracasso da reprodução do modelo original importado - conseguem, do ponto de vista dos escombros, apontar aspectos da realidade do país que permanecem cifrados, mas que podem ser compreendidos. Os autores analisados apresentaram uma espécie de dramaturgia "traumatizada e fraturada", um país em que o trauma já era o estado de coisas permanente, um modo de vida.

No entanto, há mais negativas nesse percurso, que procuraremos desenvolver no âmbito próprio a este artigo. $\mathrm{O}$ contrário dos traumas históricos, que pudemos constatar como presença melancólica nas peças, pode ser identificado em diversos procedimentos de alegorização da utopia, em uma espécie de negativo do negativo, em uma nova contradição que emerge na forma das dramaturgias para tornar seus tecidos ainda mais dilacerados, promovendo novos deslocamentos em relação ao modelo europeu. Não constatamos, nessas ruínas, apenas um trajeto de fracassos. A história da dramaturgia brasileira, em seu acúmulo de destruição mortuária, foi capaz de produzir perspectivas nas quais a imagem do país surge em deslocamento, em estranhamento, revelando suas fissuras e fendas, tal como um dia, indigente e deformado, aparecerá na luz da possível redenção histórica. Essa escrita invertida do seu contrário, emergiu quando podemos localizar, usando um termo caro a Walter Benjamin, "imagens dialéticas" presente nas peças, espécie de negação do negado: se a destruição formal negou os modelos do drama e do teatro épico europeus, esses fragmentos utópicos, puderam ser identificados como farpas a gerar incômodo e novos deslocamento na engrenagem dos textos, capazes de conferir sentidos antagônicos aos mesmos personagens, narrativas e ações. A imagem dialética é a emergência, escreve Benjamin, de um "fóssil antediluviano no curso histórico das coisas" (BENJAMIN, 2006, p. 517). Desse modo, na imagem dialética se encontram o agora e o tempo passado: o relâmpago permite perceber sobrevivências, a cesura rítmica abre o espaço para os fósseis anteriores da história, projetados em desejos de futuro.

Encontramos assim, nas peças dos autores brasileiros, impulsos subjacentes, muitas vezes na forma inconsciente, distorcida e sublimada, 
acumulados em um imaginário - fracionado e descontínuo, soterrado - do que Benjamin também chamaria de "sonhos coletivos", em seu exposé de 1935, "Paris, Capital do século XIX” :

No sonho em que, diante dos olhos de cada época, aparece em imagens aquela que a seguirá, esta última aparece intimamente ligada a elementos da proto-história, ou seja, a elementos de uma sociedade sem classes. Tais experiências, depositadas no inconsciente da coletividade, interpenetram-se no novo, gerando utopia que deixou seu rastro em mil configurações da vida, desde as construções duradouras até às modas fugazes (BENJAMIN, 2006, p. 41)

A citação acima, enfatiza o aspecto de utopia coletiva e emancipatória que confere movimento, incessante, entre as "imagens dialéticas" e as "imagens oníricas". O que chamamos de "imagens oníricas das obras teatrais", capazes de expressar esses sonhos coletivos, tratou-se, em diversas peças, de impulsos na direção da coletividade, tanto no modo como a vida social estava presente nos momentos históricos que deram luz às peças quanto na imaginação de como tais contextos deveriam ser, a partir dos ecos de sonhos e experiências coletivas passadas, não marcadas pela divisão de classes. "O que significa, porém, esta interpenetração de antigüidade e modernidade? [...] A categoria que transita de um para outro desses inseparáveis momentos relacionais, é a da imagem (Bild): imagem onírica (Traumbild), num momento; imagem dialética (dialektisches Bild), noutro". (AQUINO, 2004, p.50)

Pudemos perceber em tais imagens rastros das épocas do processo histórico brasileiro, a partir daquilo que Benjamin chamou de ler cada época por meio dos seus sonhos coletivos:

assim como aquele que dorme dá início à viagem macroscópica através de seu corpo, e assim como os ruídos e sensações de suas próprias entranhas (...) produzem, graças à inaudita acuidade de sua sensibilidade interna, imagens delirantes ou oníricas que traduzem e explicam tais sensações, assim também ocorre com o coletivo que sonha (...).É a ele que devemos seguir, para interpretar o século (...) como consequência de suas visões oníricas"(BENJAMIN, 2006, p. 434).

Benjamin chamou esse método dialético de escrever a história como a "arte de experienciar o presente como o mundo da vigília ao qual se refere o sonho" (Idem, ibd). Elaborar o passado, por meio da 
rememoração, significaria a recordação do sonho, cuja promoção tem a estrutura e o movimento teleológico do despertar: "O pensamento dialético é o órgão do despertar histórico. Cada época sonha não apenas a próxima, mas ao sonhar, esforça-se em despertar"(Idem, p.51). O método de despertar utilizado neste artigo esteve relacionado à "catar nas peças as alegorias", como catava feijão João Cabral de Melo Neto: "catar esse feijão, soprar nele, e jogar fora o leve e oco, palha e eco (MELO NETO, 2008, p.321)", acordando os sonhos coletivos presentes em cada texto.

Esse despertar dialético só pode ser compreendido por meio de um olhar alegórico para as peças, em que as alegorias "açulam a atenção, iscam com o risco"(Idem, ibd.).Mais ainda, utilizarei neste artigo a alegoria como método crítico para expressar um caminho tão antitético: inspirado pela alegoria de Pandora, que tenta dar feição a essa contradição entre ruína e esperança, destruição e utopia, encontrada nas peças teatrais que veremos a seguir. O poeta romântico Gerard de Nerval, em um conto chamado Pandora, assim nos define essa mitológica figura: "Era com efeito a ela - a ela em verdade - a quem podia aplicar-se o indecifrável enigma gravado sobre a pedra de Boloña: AELIA LAELIA" (NERVAL, 2004, p. 369). Segundo Nerval, Aelia é "uma fórmula solar, e Laelia é lunar" (Idem, p. 1119). Essa mesma ideia do andrógino luni-solar se encontra em uma Pandora de 1582, obra de Epimetheus Franciscus, uma de cujas lâminas representa essa fusão dos contrários, e que Nerval conheceu e admirou. "Nem homem, nem mulher, nem andrógino, nem jovem, nem velha, nem casta, nem louca, nem pudica, senão tudo isso junto..."(idem, ibd.) A caixa de Pandora, em que se aglutinam todos os males e bens do mundo, é imagem desse panorama histórico de formação negativa que marcou a dramaturgia no Brasil, em que a justaposição é a forma de organização dos contrários: identificamos nas obras analisadas, estruturas trágicas, movidas e paralisadas, simultaneamente, por contradições sem superação: uma dessas contradições pode ser definida como essa presença de imagem onírica e de pulsão destrutiva, corroendo o tecido de cada dramaturgia negativa.

Foi possível constatar, assim, no processo histórico brasileiro, a dialética entre esperança e catástrofe, expressa nas peças analisadas pela contradição entre função utópica e estrutura dramatúrgica arruinada, entre espera e devastação, entre repetição e inovação, deslocamento. A presença constante das imagens oníricas, corroídas sempre pela negatividade do panorama histórico de produção de ruínas, também presente na forma e 
no conteúdo dos textos, revelaria a ilusão de nossa procissão de milagres, situada, na verdade, sobre o solo revolvido da mais desavergonhada dominação de classe. É possível encontrar, nestes porões do navio fantasma em que os mortos permanecem vivos e direcionando a navegação, novamente a alegoria da caixa de Pandora: ao testarmos diversas chaves alegóricas na leitura das peças, cada uma revelou-se trancada por fechadura dupla. As caixas, então, abriram-se assim como o mar aberto com cúmulos noturnos carregados durante a tempestade; mas também, virando a chave para o lado oposto, como o mesmo mar, agora com nuvens matinais dedirróseas sobre o horizonte, quando o sol não está mais distante e tem início o dia que pode ser bem-vindo já antes do anoitecer.

A seguir, testaremos essas hipóteses sobre a formação da dramaturgia nacional na análise de duas peças brasileiras que, a despeito das intenções originais e crenças politicas dos dramaturgos, podem ser lidas sob um conceito bastante presente no pensamento de Walter Benjamin, capaz de articular esse movimento que mencionamos acima, entre imagens dialéticas e imagens oníricas, o de messianismo:

Neste caso, como havia sublinhado Gershom Scholem, há em Benjamin, como na mística judaica, uma projeção da utopia no presente. O messianismo não é mais concebido como o alcançar de uma apoteose que se produziria no termo de um tempo linear e contínuo, mas como a possibilidade, dada a cada momento do tempo, ao advento do novo: para os judeus, 'cada segundo era a porta estreita pela qual podia entrar o Messias'. (MÒSES, 1997, p. 160)

A contradição que mencionamos acima, presente em muitas peças teatrais brasileiras, entre imagem onírica e forma dramatúrgica arruinada, pode ser compreendida por meio do conceito benjaminiano de messianismo, devido à estrutura dialética deste último, capaz de conjugar a projeção da "utopia no presente", de que nos fala Mòses, com a ideia de catástrofe: "É necessário fundar o conceito de progresso sobre a ideia de catástrofe Que as coisas continuam assim -eis a catástrofe". (BENJAMIN, 2006, p. 515)

Essa concepção messiânica, inspirada no materialismo dialético, é também crítica ao progresso, que Walter Benjamin leva a cabo contra o historicismo positivista e realizada na ideia da catástrofe, entendida aqui como o momento dialético que conduz a seu extremo: a redenção messiânica. Progresso e catástrofe, marxismo dialético e messianismo, longe 
de se excluírem, em um paradoxo, entrelaçam-se, nessa visão historica, sintetizados por meio do conceito de redenção. "O termo catástrofe reenvianos para a compreensão da ruptura da continuidade histórica, momento em que, ao explodir o fluxo contínuo da história, instaura-se uma espécie de ruptura salvadora, mediante um instante apocalíptico-messiânico e, por excelência, redentor". (CANTINHO, 2002, p. 50)

Tal capacidade de imaginação de um futuro possível, que emerge das ruínas sociais sem conclusão e sem síntese e está presente nas alegorias messiânicas das peças que veremos a seguir, é capaz de apontar para constelações contraditórias da formação histórica brasileira. Procurarei, como sugere Benjamin, "ser dialético", tendo "o vento da história nas velas. As velas são os conceitos. Porém, não basta dispor das velas. O decisivo é a arte de posicioná-las". (BENJAMIN, 2006, p. 515). Voltemos, então, nossas velas para o Brasil.

\section{Fragmento 2 - Utopia e romantismo em Mãe:}

Lucien Goldmann chamou de visão de mundo "uma visão psicologicamente coerente do mundo, que pode se expressar no plano religioso, filosófico, literário ou artístico" (GOLDMANN, 1976, p.107). Ao contrário da ideologia, com seu caráter deformante, as visões de mundo estariam baseadas em totalidades, em um "ideal concernente ao conjunto da comunidade humana", em um "ideal de homem e de organização social" (Idem, ibd.). A partir dessa definição de Goldmann, Michael Lowy e Robert Sayre, em seu livro Revolta e melancolia, tomaram o romantismo como uma estrutura mental coletiva, não se limitando à literatura e à arte, ou ao período histórico em que se desenvolveram os movimentos ditos românticos. Para os autores, a visão de mundo romântica "representa uma crítica da modernidade, isto é, da civilização capitalista, em nome de valores e ideais do passado (pré-capitalista, pré-moderno). Pode-se se dizer que desde a sua origem o romantismo é iluminado pela dupla luz da estrela da revolta e do sol negro da melancolia (Nerval)" (LOWY; SAYRE, 2015, p. 38-39). Essa visão se apresentaria como um conjunto de imagens oníricas articulado segundo uma lógica, como uma "estrutura significativa - não necessariamente consciente (em geral, até não consciente) - subjacente a uma diversidade muito grande de conteúdos e formas de expressão. Por estrutura significativa (...) entendemos uma totalidade coerente organizada em torno de um eixo, de uma viga" (Idem, 
ibd.). Para os autores, essa viga, capaz de articular a totalidade de que estamos falando, seria: "O romantismo como visão de mundo constituise enquanto forma específica de crítica da modernidade"(Idem, ibd.).

É possível perceber em Mãe, peça de José de Alencar, uma oposição à realidade capitalista brasileira, por meio de uma forma dramática, que mimetiza o trajeto da mercadoria, e por personagens contaminados pela reificação, pela desumanização advinda do modo de produção escravista, marca da inserção do país no sistema do capitalismo global. Sob esse prisma, seria possível identificar na peça uma visão de mundo romântica e anticapitalista. Até mesmo o amor "romântico" entre o casal da peça, que leva o herói a vender sua própria mãe/escrava para pagar as dívidas do futuro sogro, poderia ser lido como Max Weber dizia: "essa entrega sem limite é tão radical quanto possível em sua oposição a toda funcionalidade, racionalidade e generalidade"(WEBER, 2010, p. 397).

No entanto, o quadro histórico brasileiro do período era distinto: o país vivia as contradições da herança colonial e do sistema escravista, e a "modernidade"- definida como a civilização engendrada pela Revolução Industrial e pela generalização da economia liberal e de mercado - era aguardada por aqui, como uma panaceia capaz de resolver todas as nossas formas de atraso. O próprio Alencar, de convicções políticas conservadoras, chegou a se posicionar contra a abolição dos escravos, sob a alegação de que

Nós queremos a redenção de nossos irmãos, como a queria o Cristo. Não basta para vós dizer à criatura, tolhida de sua inteligência, abatida na sua consciência: "Tu és livre; vai; percorre os campos com uma besta fera".[...] Não Senhores, é preciso esclarecer a inteligência embotada, elevar a consciência humilhada, para que um dia, no momento de conceder-lhe a liberdade, possamos dizer: "Vós sois homens, sois cidadãos. Nós vos redimimos não só do cativeiro, como da ignorância, do vício, da miséria, da animalidade em que jazíeis!" [...]Queremos fazer homens livres, membros úteis da Sociedade, cidadãos inteligentes, e não hordas de selvagens atiradas de repente no seio de um povo culto" (ALENCAR, 2000, p. 228-229).

Para Alencar, nesse discurso proferido em 1871, sem que a sociedade brasileira se modernizasse, seria impossível abolir a escravidão. A escravidão teria, naquele momento, que cumprir sua missão histórica: produzir o amálgama das raças, civilizando o negro a partir do trabalho e 
do seu contato com uma "raça culta". Só então poderia o negro assumir uma posição de liberdade no interior de um mercado de trabalho já formado e de uma sociedade que oferecesse oportunidades iguais para todos, conquistando assim os seus direitos de cidadão já "habilitado como criatura racional". Não muito diferente do que ocorreu com o índio, que teve de escolher o extermínio para transformar-se em herói, o negro haveria de se sacrificar para adquirir o direito à emancipação. Aos olhos de hoje, tais ideias soam como violentas - na defesa do cativeiro - e reacionárias, à luz de um processo de modernização que não ocorreu. Seria possível então falar em visão de mundo romântica na peça de Alencar nesse contexto de espera pela modernidade e não de crítica, mesmo considerando os conteúdos inconscientes, implícitos e mediatizados que o conceito de Goldmann abrange ?

Em uma primeira leitura, parece-nos que estamos, depois de analisar a peça de Alencar, diante de uma obra que configura aquilo que, a partir de um termo empregado por Engels acerca de Balzac, Lukács convencionou chamar de triunfo do realismo:

Esta [a realidade histórica] pode ser retratada com "falsa consciência", isto é, de um modo em que o autor condena o presente em que vive e que descreve, afirmando conscientemente ou uma sociedade passada e que está perecendo, ou uma utopia presente apenas na sua imaginação, mas, não obstante, ainda reconhecendo, indicando e figurando em seu retrato as forças motrizes em sua interconexão, o que Engels considerava "um dos grandes triunfos do Realismo"(LUKÁCS, 2011, p. 53).

O que caracteriza a arte aqui denominada realista não é a perspectiva professada pelo autor, que pode dirigir-se a um passado idealizado, como nos casos de Balzac e Tolstoi, ou a um futuro utopicamente concebido. O que a caracteriza é o reconhecimento e figuração, na criação literária, das forças motrizes da realidade, algo que o autor revela na construção artística de maneira mais ou menos independente da sua própria consciência ou ideário. Quer dizer, o processo total pode ser retratado na obra literária mesmo com falsa consciência: a superação do fetichismo deve levar-se a efeito na criação literária, ainda que isso contradiga a opinião professada pelo escritor. No entanto, em vez de triunfo do realismo - não podemos chamar a peça de Alencar de realista, mas antes seria possível identificar, em sua forma, a justaposição de procedimentos do drama burguês realista e de uma visão de mundo 
romântica - , a análise da figuração utópica em Mãe pode revelar novos aspectos do processo de formação histórica do Brasil. Podemos encontrar as pistas para esse percurso não nos discursos do escritor, mas na sua própria criação literária: na mesma alegoria empregada em três de seus romances, e reproduzida no desfecho de Mãe.

Em As minas de prata, no final do romance, encontramos a alegoria do país utópico e reconciliado, entre o arvoredo, na modesta,

mas graciosa habitação de Estácio situada à margem de um rio, (...), formando uma quase ilha, do feitio de coração. Se o amor reside no grande músculo humano, sem dúvida aquela mansão deveria ser essa mesma forma (ALENCAR, 1964, p. 880).

Já em $O$ tronco do ipê, a cabana de pai Benedito é sustentada na encosta de um penhasco:

No fim da planície corria uma cadeia de penhascos, que descia verticalmente das altas colinas e submergia-se no leito do rio. O mais saliente desses penhascos sustentava na encosta uma cabana de sapé. A abóbada da caverna, onde as águas se precipitavam, era naturalmente o cimo do penhasco onde estava a cabana, porque só nesse ponto se escutava bem o surdo fragor da catadupa.(Idem, p. 540).

Por fim, em O guarani, a casa de Dom Antonio de Mariz também se localiza à beira de um abismo :

via-se à margem direita do rio uma casa larga e espaçosa, construída sobre uma eminência e protegida de todos os lados por uma muralha de rocha cortada a pique. [...]Descendo dois ou três dos largos degraus de pedra da escada, encontrava-se uma ponte de madeira solidamente construída sobre uma fenda larga e profunda que se abria na rocha.(Idem, p. 27-28).

A alegoria da casa emerge dos romances em duplo aspecto: ora como abrigo e identificação com a natureza do arvoredo e do coração, ora como ilha ou fortaleza, suspensa sobre o abismo do mundo. Esses dois aspectos também surgem na casa de Jorge, espaço da ação principal de Mãe: 
GOMES - Não tenho consentimento a dar... Faço um voto pela felicidade de ambos.

DR. LIMA - Isto é mais claro. Marquemos o dia.

GOMES - O Sr. Jorge dirá.

ELISA - Já!... Que pressa!

JORGE - Elisa é quem deve marcar.

ELISA - Eu não!

DR. LIMA - Pois marco eu. E aposto que vão todos ficar satisfeitos.

Que dia é hoje? (...) Em três dias faz-se um vestido... Sábado!

GOMES - Muito bem.

JORGE - Concordo.[...] A casa já está pronta. (ALENCAR, 1964a, p. 340).

Por meio do confronto com os romances, é possível identificar, no espaço privado da ação dramática da peça, a casa burguesa como alegoria de um país reconciliado em um novo mundo: o final da narrativa, edifica por sobre o cadáver da escrava Joana a fundação de um país livre, de comunhão entre todas as raças, identificado pela força solidária do amor romântico, em que "a alma é mais vasta que os destinos que a vida pode oferecer" (LUKÁCS, 200, p. 117). O fato de o casamento de Jorge superar os "destinos da vida", a desaprovação do sogro, baseada na origem de Jorge, filho bastardo da escrava Joana, configura a casa como o lar burguês do progresso, em uma utopia romântica do país novo, liberal e desenvolvido.

Para Walter Benjamin, o sentimento de privação do lar e isolamento tornou-se a experiência fundamental dos românticos do início do século XIX. O filósofo, também ele fortemente impregnado da visão de mundo romântica, vê no apelo dos românticos alemães à vida onírica um aviso de emergência, uma indicação dos obstáculos que a vida real ergue no "caminho que a alma deve tomar para retornar ao lar"(BENJAMIN, 2013, p. 169). Haveria assim, no romantismo, um desejo ardente de reencontrar o lar, retornar à pátria, no sentido espiritual, em uma nostalgia que estabelece no passado o período em que as alienações modernas ainda não existiam: "a nostalgia de um paraíso perdido acompanha-se no mais das vezes de uma busca do que foi perdido"(LOWY; SAYRE, 2015, p. 45).

A diferença da utopia romântica de Alencar é que o seu lar burguês está deslocado para o futuro: o casamento entre Jorge e Elisa será realizado, a peça termina antes de sua concretização. O filho de 
escrava e o sogro, burguês empobrecido pelas dívidas, irão morar na mesma casa, em um mesmo lar burguês. $\mathrm{O}$ final da peça, ao contrário do que apregoa a estrutura do drama, aponta para o futuro: apenas em um futuro reconciliado, livre da escravidão e em uma sociedade que os seus trabalhadores livres empobrecidos pudessem encontrar ocupação o casamento entre Jorge e Elisa seria possível. Ao contrário do drama burguês, a peça de Alencar não está construída para veicular os valores da burguesia do presente: em olhar para o passado, Alencar recorre aos ideais da burguesia europeia, revolucionária e romântica do século XVIII para alegorizar, contemplando um futuro utópico, um lar nascido sobre os penhascos e a partir dos valores do sentimento purificado -"loucura em comum deixa de ser loucura e se torna magia"(LUKACS, 2000, p. 143) - em que o país seria "romantizado por uma potenciação" da realidade banal e habitual, "romantizar nada é senão uma potenciação qualitativa. $\mathrm{Na}$ medida em que dou ao comum um sentido elevado, ao costumeiro um aspecto misterioso, ao conhecido a dignidade do desconhecido, ao finito um brilho infinito, eu o romantizo"(NOVALIS, 1998, p. 142).

Giorgio Agamben, em um ensaio sobre as cartas de Paulo, propõe a seguinte definição para o tempo messiânico: "é o tempo que o tempo nos dá para acabar - ou mais exatamente o tempo que empregamos para realizar a conclusão, para completar nossa representação do tempo" (AGAMBEN, 2006, p. 72). Este tempo não é uma linha do tempo cronológico, nem o instante do fim; "é o tempo operativo que urge no tempo cronológico, que o elabora desde o interior, tempo de que temos necessidade para concluir o tempo...e, nesse sentido, é o tempo que resta" (Idem, ibd.). O "tempo que resta" não é um tempo suplementar, que se acrescenta ao tempo cronológico para diferir indefinidamente o fim. $\mathrm{O}$ tempo messiânico, sem coincidir jamais com o tempo cronológico e sem somar-se a ele, o apreende e o leva a seu cumprimento desde o interior:

a decomposição paulina da presença messiânica se assemelha à contida em uma extraordinária alegoria kafkiana, segundo a qual o messias não chega no dia de sua vinda, senão apenas um dia depois, não no último dia, senão no ultimíssimo. O messias tem chegado já; o evento messiânico já tem se cumprido, mas sua presença contém em seu interior outro tempo, que estende a presença do messias, mas não para diferi-la, pelo contrário, para fazê-la apreensível (AGAMBEN, 2006, p. 75). 
A alegoria de Kafka reúne dois fragmentos, ambos escritos em dezembro de 1917:

O Messias chegará quando seja possível o mais desenfreado individualismo na fé, e ninguém destrua essa possibilidade, e ninguém para sofrer sua destruição, quer dizer, quando se abram as tumbas. O Messias não virá até que já não seja necessário, e mais, chegará depois de sua própria vinda, não virá no último dia, senão no dia posterior ao último, no ultimíssimo dia (KAFKA, 2003, p. 621).

A parábola de Kafka é obscura até que a interpretemos a partir da ideia de tempo messiânico, conforme definida por Benjamin. O Messias não virá como um indivíduo e, certamente, não dentro de nenhuma sequência temporal que nós utilizamos para organizar nosso tempo. Se ele vier no último dos últimos dias, mas não no último, ele virá em um "dia" que está além de qualquer calendário, e além da própria cronologia. A parábola postula uma temporalidade messiânica em que ninguém sobreviverá. Ela não se dá em um momento no tempo, mas no interior do tempo, quando for possível apreender que a sequência de todos os momentos foi cumprida. É este tempo, o do instante messiânico, que configura a imagem utópica, não em um futuro indefinido, mas em uma perfeita atualidade, num tempo vindouro que pode irromper a cada instante, o instante messiânico ou aquilo a que Benjamin chamará mais tarde "a estreita porta por onde chegará o Messias" (BENJAMIN, 2014, p. 706). No aparente desfecho ausente do drama de José de Alencar, em que a instauração de um outro tempo é anunciada, seria possível perceber a "a porta estreita", tão breve quanto fulgurante, o indefinível instante em que a redenção acontece, reunindo o Outrora e o Agora, em uma imagem que explode no céu estelar do conhecimento histórico. Assim, o tempo messiânico implica uma transformação da experiência do tempo, capaz de interromper, desde dentro, o aqui e agora do tempo profano. Trata-se de uma constelação temporal, de uma unidade entre os dois tempos - messiânico e cronológico - que pressupõe a ideia de que o passado está contido no presente: por meio da realização do tempo messiânico os eventos do passado adquirem seu verdadeiro significado e se transformam em fatos que serão salvos.

Essa romantização do mundo, configurada pelo olhar messiânico desse drama que pisando cadáveres sonha com o porvir, não deve ser 
avaliada sem mediações, a saber, sem a pretensão de definir se a alegoria final do sonho em Mãe realizou-se "corretamente"; a questão que nos interessa é voltar-se, muito antes, para a constelação histórica da qual brota a referida imagem utópica de Alencar. O drama de Alencar aponta que, por meio da morte absoluta da realidade existente, poderia emergir uma nova constelação histórica. Nesse modo de produção de cadáveres e de destruição, que a peça toda alegoriza, a própria forma dramática seria capaz de autodestruir-se e, em uma virada negativa surpreendente, voltar-se para o futuro.

\section{Utopia e tempo messiânico em Álbum de família:}

Na peça Álbum de família, de Nelson Rodrigues, o personagem Nonô, funciona em como a alegoria da bestialidade, de uma espécie de subjetividade selvagem, anti-civilizatória, "possessa", como caracteriza o autor na rubrica inicial de apresentação e nos diálogos dos demais personagens:

D. SENHORINHA- Estou cansada, farta, de não falar, de esconder há tanto tempo as coisas que eu sinto, que eu penso. Podem dizer o que quiserem. Mas eu dei graças a Deus quando minha filha morreu!...

HELOÍSA- E toda a família é assim. Esse Nonô, esse doido, anda no mato nu - como um bicho. Apanha terra, passa na cara, no nariz na boca!..(RODRIGUES, 1997, p. 565).

A função utópica de Álbum de família parece estar concentrada no destino de Nonô, já que, em meio ao final trágico da peça, ficamos sabendo na última rubrica que "D. Senhorinha parte para se encontrar com Nonô e se incorporar a uma vida nova. Jonas morre" (RODRIGUES, 1997, p. 595). O mesmo personagem apontado como o "possesso", em quem identificamos a destruição da ideia libertária de sujeito dramático - autônomo e livre para exercer suas escolhas - , surge também como possibilidade de felicidade e de vida nova.

Mencionamos acima que o tempo messiânico é uma espécie de tempo restante: é aquele da espera pelo Messias, que o apóstolo Paulo conclama (1 Cor 7, 29-31) que saibamos agir como se não: "Isto, porém, vos digo, irmãos, que o tempo se contrai; o que resta é que também os que têm mulheres sejam como se não as tivessem; e os que choram, como se não chorassem; e os que folgam, como se não folgassem; e os que compram, como se não possuíssem; E os que usam deste mundo, 
como se dele não abusassem, porque a aparência deste mundo passa". Nonô age como se não fosse homem, como se não comesse, como se não pensasse, como se não falasse, cerca a casa como se não a cercasse, ameaça os familiares como se não os ameaçasse: instaura assim o tempo messiânico da espera; torna inoperante o tempo. O tempo messiânico não é assim o da destruição, mas sim o da desativação: Nonô desativa o tempo do drama, tornando-o inoperante. $\mathrm{O}$ eterno retorno do sempre igual, presente na linha de ação de Álbum de família, advém dessa inoperância do tempo da espera.

No plano da forma dramatúrgica, o como se não, da instrução paulina, passa ao drama de Nelson Rodrigues, que se torna um drama inoperante: como se não fosse drama, como se não tivesse ação, como se não houvesse sujeitos. Tudo está presente como no drama moderno europeu, mas em estado de como se não. A alegoria invade o drama e o faz importante porque está presente para figurar outra realidade, ausente: a da redenção, a da realização do tempo messiânico, que trará a vida nova aguardada por D. Senhorinha. Esse instante se realiza, cumprindo o tempo da promessa, quando o patriarca morre e D. Senhorinha está livre para viver no interior do tempo de Nonô, alegoria da liberdade e da negação de todo o horror, tornado então inoperante, que fora apresentado na peça.

O tempo messiânico representado por Nonô é o tempo da esperança: "Florença, Batistério. No portal, a 'Spes'( Esperança) de Andrea Pisano. Está sentada e ergue, desesperada, os braços para um fruto que não alcança. E no entanto é alada. Nada de mais verdadeiro" (BENJAMIN, 2004a, p. 47). Há, na alegoria da escultura descrita por Benjamin, uma contradição entre espera, desespero e esperança. Bloch também descreve a mesma escultura

embora seja alada, ela está assentada esperando e, apesar das asas, levanta os braços, como Tântalo, na direção de uma fruta fora do seu alcance. Portanto, a esperança, sendo bem menos aquinhoada do que a memória, pode parecer um mal se tomada pelo lado da incerteza, e a esperança ilusória, infundada, certamente o é. (...) Tanto mais distante do mal está a esperança bem fundada, isto é, mediada pelo possível real, tão distante até do fogo-fátuo; ela representa justamente a porta no mínimo entreaberta que parece levar a objetos agradáveis, num mundo que não se tornou uma prisão (BLOCH, 2005, p.327). 
O gesto de frustração contido na alegoria é, para Benjamin, ao contrário de Bloch, sua verdade: a verdade da Spes consiste na não intencionalidade do seu gesto. A esperança autêntica não se relaciona, portanto, como em Bloch, a uma tendência possível na história, mas é sim uma espécie de força messiânica em contradição à tendência do processo histórico. Daí que seu Angelus Novus e sua leitura da Spes, de Pisano, não se dirijam a nenhum futuro, senão ao passado: na recordação, tornam-se reconhecíveis forças messiânicas que estavam ocultas na história: o instante da recordação é o instante do perigo; nele a imagem da recordação entra involuntariamente no presente:

estas imagens aparecem, como se sabe, de forma involuntária. História em sentido estrito é, portanto, uma imagem procedente da rememoração involutária, uma imagem que se apresenta subitamente ao sujeito da história no instante do perigo (BENJAMIN, 2010, p. 37).

A força messiânica em Álbum de família não foge a essa dialética entre a morte encontrada no passado, e permanente no presente, e o vislumbre da esperança do porvir. Na peça de Nelson Rodrigues o tempo messiânico e a alegoria do Messias bestial tornam-se chave para a leitura e compreensão do texto e de sua estrutura.

A esperança voluntária, que nos menciona Bloch, surge na existência de Nonô, promessa de vida nova para a mãe e de destruição do presente para os demais personagens. Nessa dualidade messiânica, de redenção e de "inoperância", de homem e de besta, Nonô aproximase também de outra alegoria da esperança, a de Pandora. Em uma das tentativas de confissão realizadas por D. Senhorinha, ficamos sabendo que todo o mal que assola a família iniciou-se com sua relação incestuosa com Nonô: a partir daquele instante, o filho teria enlouquecido, fugindo e vivendo nas matas, bem como Jonas e os outros filhos teriam começado a agir com estranheza e violência. Segundo essa leitura, Nonô seria o responsável por abrir a caixa de desgraças, trazendo a ruína ao mundo familiar. Mas há na atitude de espera de D. Senhorinha - confirmada no final reconciliado que a peça apresenta - uma outra leitura para a imagem da caixa de Pandora trazida por Nonô. $O$ dote de Pandora seria aqui não o recipiente da desgraça, mas, pelo contrário, de mistérios e mudanças vindouras. Nonô seria aqui a própria Pandora, que significa "a onidotada, cheia de atrativos, presentes, benefícios" (BLOCH, 2005, p.327). 
De acordo com essa versão do mito, também estes teriam saído da caixa, mas, diferentemente dos vícios, eles de fato teriam fugido por completo, não se espalhando entre os homens; teria permanecido na caixa, como único bem, a esperança: " a esperança sustenta o ânimo para buscar os bens faltantes, a constância e a não-resignação diante dos bens que não comparecem, e, onde ela desaparece, o processo em curso no mundo se perde" (Idem, ibd.). A esperança que Nonô oferece, e a temporalidade messiânica que instaura, mostra a esperança como o único bem que resta, que de forma alguma tornou-se realidade madura no tempo, mas que também não foi destruído. A porta estreita e entreaberta do messias em Álbum de família designa a esperança como a caixa de Pandora do mundo inconcluso - e do próprio drama inconcluso, já que não vemos na narrativa o final de Nonô e D. Senhorinha, que apenas é anunciado, profetizado.

Ao contrário da casa-grande da fazenda, em que se passa a maior parte da trama, que abriga os pecados históricos de uma classe, a caixa trazida por Nonô se abre como o aposento amplo e aquecido, como o camarote em terra, no qual arde a luz promissora do lar. Estamos novamente diante da alegoria do lar, mas aqui, ao contrário de Alencar, o lar representa, um século depois, a inoperância vindoura do lar burguês e do lar do drama: a temporalidade messiânica surge para ameaçar ambos e, se a destruição não se cumpre, o drama resta corrompido e a figura da esperança relampeja, mesmo que apenas como possibilidade abstrata.

As formações materiais do mundo - e a formação do Brasil também, nosso objeto de análise - até ao desencadeamento da força produtiva mais intensiva, do verdadeiro núcleo atômico do existente - estariam assim repletas da tendência do "ainda-não", mencionado por Bloch. No caso de Álbum de família parece que a imagem utópica alegorizada por Nonô - sua negação da vida familiar dos proprietários seguida por sua constante ameaça de invasão da casa-grande e de destruição, funcionando, ao mesmo tempo, como uma espécie de "retorno do negado" - relaciona-se a um mundo determinado, em que "as contradições impelem para diante, em que a possibilidade de desenvolvimento para diante tem espaço" (Idem, p,328), e esse mundo está situado em um drama em que a barbárie e a civilização não são apenas sequenciais, mas sincrônicas - e que a civilização burguesa surge interligada à elite patriarcal e escravista brasileira, marcando uma forma sublimada de violência e agressão. 
Assim como a temporalidade messiânica corrói o drama, tornando-o eterno retorno do sempre igual da espera, a violência irrompe pelas formas de repressão empregadas pela instituição familiar e proprietária, deixando entrever por suas frestas e ruínas a possibilidade de redenção. A barbárie alegorizada pela vida de Nonô mostra-se como uma das condições mal-disfarçadas e subjacentes ao que chamamos de civilização no Brasil. A violência que fundou o estado colonial e escravista brasileiro não cedeu espaço a uma civilidade liberal ou democrática posterior. Ao contrário, o controle reprimido - e em equilíbrio precário - da agressividade de Nonô parece alegorizar a missão sublimada de "manter a Natureza sob controle, sem o que a civilização tem dificuldade para sobreviver" (EAGLETON, 2011, p. 91). Nonô revela à civilização, tal como essa se formou no Brasil, algo de seu próprio eu secreto repudiado: "No âmago da liberdade espreita certa coerção, exatamente como a razão é sempre infiltrada por seu oposto" (Idem, p. 92). Nonô representa o oposto da modernização capitalista no Brasil, com o seu progresso infiltrado nas formas mais selvagens de dominação. Por outro lado, estamos diante de uma alegoria da negação absoluta e da possibilidade utópica baseada na promessa messiânica de um mundo do não-eu. Esse não-eu, representado por Nonô, surge na peça por meio de um quase rompimento com drama: o "como se não paulino", gera uma obra tensa, como se não fosse dramática, mas ainda dramática, como se não fosse moderna, mas ainda moderna. Na verdade, a novidade do texto advém dessas polaridades, em que a forma dramática ameaça ser colocada abaixo, como a casa-grande da narrativa, mas ainda permanece de pé, à espera. $\mathrm{O}$ drama não é abandonado de todo e essa sua permanência incômoda transmite-nos o tempo messiânico da utopia e da incompletude: o não-drama e a não-narrativa - apesar das ameaças do tempo repetido, da subjetividade individual negada, do diálogo trocado pela confissão monológica - não se realizam, assim como o tempo messiânico também ainda não se cumpre, ainda. O final do texto, também interrompido, apresenta-nos a possibilidade da esperança - refletida na própria forma da peça, que figura a derrubada do drama, sem se consumar -, esperança que está guardada em uma caixa aberta, esperando por Nonô e por nós em algum lugar.

A Nathalia, instante messiânico, ultimíssima lua 


\section{Referências}

AGAMBEN, Giorgio. El tiempo que resta. Comentario a la carta a los romanos. Madrid: Trotta, 2006

ALENCAR, José. Obras completas. Rio de Janeiro: Aguilar, 1964. v. II. ALENCAR, José. Obras completas. Rio de Janeiro: Aguilar, 1964a. v. IV.

ALENCAR, José. Discursos parlamentares de José de Alencar. Brasília: Câmara dos Deputados, 2000

AQUINO, João E. Fortaleza de. Imagem onírica e imagem dialética em Walter Benjamin. Revista de Filosofia do Mestrado Acadêmico em Filosofia da UECE, Fortaleza, v. 1, n. 2, p. 45-72, 2004.

BENJAMIN, Walter. Origem do drama trágico alemão. Lisboa: Assírio \& Alvim, 2004.

BENJAMIN, Walter. Imagens de pensamento. Lisboa: Assírio \& Alvim, 2004a.

BENJAMIN, Walter. Passagens. Belo Horizonte: Ed. UFMG; São Paulo: Imprensa Oficial, 2006.

BENJAMIN, Walter. O anjo da história. Lisboa: Assírio \& Alvim, 2010.

BENJAMIN, Walter. O capitalismo como religião. São Paulo: Boitempo, 2013.

BENJAMIN, Walter. Obras completas. Madrid: Abada, 2014. v. 1, 2.

BLOCH, Ernst. O princípio esperança. Rio de Janeiro: EdUERJ; Contraponto, 2005. v. I.

CANDIDO, Antonio. Formação da literatura brasileira. Belo Horizonte: Ed. Itatiaia; São Paulo: Ed. da Universidade de São Paulo, 1975.

CANDIDO, Antonio. Literatura e Subdesenvolvimento. In: . A educação pela noite e outros ensaios. São Paulo: Ática, 1989.

CANTINHO, Maria João. O anjo melancólico. Lisboa: Angelus Novus, 2002.

EAGLETON, Terry. O debate sobre Deus. Razão, fé e revolução. Rio de Janeiro: Nova Fronteira, 2011. 
GOLDMANN, Lucien. Ciências humanas e filosofia. Rio de Janeiro; São Paulo: Difel, 1976.

JAMESON, Fredric. As marcas do visível. Rio de Janeiro: Graal, 1995. KAFKA, Franz. Obras completas III. Galaxia Gutenberg, 2003.

LOWY, Michael e SAYRE, Robert. Revolta e melancolia. São Paulo: Boitempo, 2015.

LUKACS, Gyorg. A teoria do romance. São Paulo: Ed. 34, 2000.

LUKÁCS, Gyorg. Escritos de Moscú. Estudios sobre la política y literatura. Buenos Aires: Gorla, 2011.

MELO NETO, João Cabral de. Catar Feijão. In: . Poesia completa e prosa. Rio de Janeiro: Aguilar, 2008.

MOSÈS, S. El angel de la história. Madrid: Cátedra, 1997.

NOVALIS. Pólen. São Paulo: Iluminuras, 1998.

PASTA JR., José Antonio. Uma conversa com José Antonio Pasta. Sinal de menos, v. 4, Ano 2, p. 5-11, 2010. Disponível em $<$ https://sinaldemenos. org/2011/02/24/sinal-de-menos-4>. Acesso em: 8 out. 2018.

RODRIGUES, Nelson. Teatro completo. Rio de Janeiro: Nova Aguilar, 1997.

SCHWARZ, Roberto. Sequências brasileiras. São Paulo: Cia. das Letras, 1999.

WEBER, Max. Rejeições religiosas no mundo e suas direções. In: . Ensaios de sociologia. São Paulo: LTC, 2010.

Recebido em: 17 de outubro de 2018 Aprovado em: 8 de novembro de 2018 